\title{
Diet-induced pseudohypoparathyroidism: A hypocalcemia and milk fever risk factor
}

\author{
J. P. Goff, ${ }^{\star 1,2}$ A. Liesegang, $†$ and R. L. Horst ${ }^{\star 3}$ \\ ${ }^{*}$ Periparturient Diseases of Cattle Research Unit, National Animal Disease Center, US Department of Agriculture-Agricultural Research Service, \\ Ames, IA 50010 \\ †Institute of Animal Nutrition, Vetsuisse Faculty University of Zurich, Winterthurerstr. 260, 8057 Zurich, Switzerland
}

\begin{abstract}
Subclinical hypocalcemia may affect half of all multiparous cows, and clinical hypocalcemia or milk fever affects approximately $5 \%$ of dairy cows each year. This disorder of calcium homeostasis can be induced by several dietary factors. Recent studies implicate high dietary potassium and high dietary cation-anion difference (DCAD) with increased risk of milk fever. The hypothesis tested in this study was that high-DCAD diets fed to prepartum cows reduce tissue sensitivity to parathyroid hormone (PTH), inducing a pseudohypoparathyroid state that diminishes calcium homeostatic responses. Multiparous Jersey cows were fed low- or high-DCAD diets in late gestation, creating a compensated metabolic alkalosis in the high-DCAD cows and a compensated metabolic acidosis in the low-DCAD cows. They then received synthetic PTH injections at 3-h intervals for $48 \mathrm{~h}$. Parathyroid hormone is expected to cause an increase in plasma calcium by increasing renal production of 1,25-dihydroxyvitamin $\mathrm{D}$ and increasing bone calcium resorption. Plasma calcium concentration increased at a significantly lower rate in cows fed the high-DCAD diet. Cows fed the high-DCAD diet also produced significantly less 1,25-dihydroxyvitamin D in response to the PTH injections than cows fed the low-DCAD diet. Serum concentrations of the bone resorption marker carboxyterminal telopeptide of type I collagen were numerically lower in cows fed the highDCAD diet but this difference was not statistically significant. These data provide direct evidence that high-DCAD diets reduce tissue sensitivity to PTH. The metabolic alkalosis associated with high-DCAD diets likely induces a state of pseudohypoparathyroidism in some dairy cows at the onset of lactation, resulting in hypocalcemia and milk fever.
\end{abstract}

\footnotetext{
Received September 8, 2013.

Accepted November 18, 2013.

${ }^{1}$ Corresponding author: jpgoff@iastate.edu

${ }^{2}$ Current address: College of Veterinary Medicine, Iowa State University, Ames, IA 50011.

${ }^{3}$ Current address: Heartland Assays, 2711 South Loop Dr., Ames, IA 50010.
}

Key words: milk fever, pseudohypoparathyroid, dietary cation-anion difference

\section{INTRODUCTION}

Milk fever is the common name given to a severe, acute hypocalcemic condition occurring in 5 to $6 \%$ of all dairy cows within days of calving. Subclinical hypocalcemia, defined as plasma Ca concentration $<8$ $\mathrm{mg} / \mathrm{dL}$, affects about $50 \%$ of all multiparous cows and $25 \%$ of heifers (Reinhardt et al., 2011). Hypocalcemia occurs because the mammary gland demand for $\mathrm{Ca}$ at the onset of milk production draws Ca from the plasma and extracellular fluid $\mathrm{Ca}$ pool faster than it can be replaced. As cows develop hypocalcemia, they respond rapidly by increasing secretion of parathyroid hormone (PTH). In cows that do not develop subclinical hypocalcemia or the clinical hypocalcemia of milk fever, PTH rapidly activates Ca homeostatic mechanisms such as renal re-absorption of urinary calcium, osteoclastic bone resorption, and increased renal production of the hormonal form of vitamin $\mathrm{D}, 1,25$-dihydroxyvitamin $\mathrm{D}$ $\left[\mathbf{1}, \mathbf{2 5}(\mathrm{OH})_{2} \mathrm{D}\right]$ to enhance intestinal absorption of dietary Ca (Ramberg et al., 1984). When Ca homeostatic mechanisms are functioning properly, only a small decline in blood Ca occurs. More severe hypocalcemia occurs when these mechanisms are not rapidly or fully initiated. At one time, it was thought that milk fever occurred as a result of failure of the parathyroid gland to recognize and respond to the hypocalcemia developing at the onset of lactation and that excessively high dietary $\mathrm{Ca}$ in the prepartum ration caused the parathyroid gland dysfunction (Capen and Young, 1967). However, it was later discovered that cows developing milk fever have very high concentrations of PTH in their blood (Mayer et al., 1969). In a landmark study, Martig and Mayer (1973) were able to demonstrate that the response of late-gestation cows to exogenous PTH (an increase in blood Ca) was diminished compared with the response elicited by PTH in cows in lactation, but they were not able to discern the cause. In severe cases of "relapsing" milk fever (cows relapsing and becoming recumbent again some hours after the 
typical intravenous calcium treatment), it was observed that the secreted PTH in these cows failed to stimulate production of $1,25(\mathrm{OH})_{2} \mathrm{D}$ as quickly as it does in cows with less severe hypocalcemia (cows that require only a single intravenous calcium treatment to effect a recovery), suggesting again that the periparturient cow's tissues could be temporarily refractory to PTH. In that study, the cows were fed a diet with alfalfa hay as the forage, which would be considered a high-DCAD diet (Goff et al., 1989).

Several meta-analyses have been done concerning risk factors for milk fever. Oetzel (1991), working with a limited number of studies at the time, concluded that dietary $\mathrm{S}$ content and DCAD using the equation utilizing milliequivalents of $(\mathrm{Na}+\mathrm{K})-(\mathrm{Cl}+\mathrm{S})$ most accurately reflected the risk of a diet causing milk fever. That analysis indicated that the milk fever incidence was highest when diet Ca was $1.16 \%$ and that dietary Ca well above or well below $1.16 \%$ had a preventative effect against milk fever. A few years later, Charbonneau et al. (2006) concluded that the DCAD equation utilizing milliequivalents of $(\mathrm{Na}+\mathrm{K})-(\mathrm{Cl}+0.6 \mathrm{~S})$ was the best predictor of clinical milk fever risk, reducing the importance of dietary $\mathrm{S}$ and determining that an important aspect of DCAD manipulation was an alteration of acid-base status. Lean et al. (2006) concluded that the DCAD equation utilizing milliequivalents of $(\mathrm{Na}+\mathrm{K})-(\mathrm{Cl}+\mathrm{S})$ accurately reflected the risk of a diet causing milk fever and that the risk of milk fever was greatest with diets that had 1.1 to $1.3 \% \mathrm{Ca}$. Their analysis pointed out a pivotal role for inadequate diet $\mathrm{Mg}$ as a very strong milk fever risk factor. Their models also demonstrated that excessive diet phosphorus was another milk fever risk factor.

Decreasing the DCAD, defined as the difference in the number of milliequivalents of cations (primarily $\mathrm{K}$ and $\mathrm{Na}$ ) and anions (primarily $\mathrm{Cl}$ and $\mathrm{S}$ ) in the diet, improves $\mathrm{Ca}$ homeostasis at the onset of lactation (Ender et al., 1971). Ender et al. (1971), Dishington (1975), and Block (1984) demonstrated that adding acidogenic chloride and sulfate anions to the cows' diet in the final weeks of gestation could prevent milk fever. Goff and Horst (1997) demonstrated that high dietary $\mathrm{K}$ increased the risk of a cow developing milk fever. The high dietary $\mathrm{K}$ content induced metabolic alkalosis in the cows. They noted that the risk of developing severe hypocalcemia at the onset of lactation was greatest in those cows in a state of metabolic alkalosis. Similar results were observed when Na was added to the prepartum diet. The mechanism by which addition of anions to a diet to counteract cations in the diet of a cow enhances Ca homeostasis is not well understood. Leclerc and Block (1989), Goff et al. (1991), and Phillippo et al. (1994) provided indirect evidence that physiological functions stimulated by $\mathrm{PTH}$, such as bone resorption and production of $1,25(\mathrm{OH})_{2} \mathrm{D}$, were enhanced in cows fed diets with added anions. Unfortunately, differences in milk production, sequestration of $\mathrm{Ca}$ in the mammary gland before calving, inappetence on the day of calving and feed intake after calving, and other metabolic stressors (negative energy, protein imbalance) occur on the first day of lactation. This causes difficulty when trying to discern how and why tissues might become refractory to PTH stimulation in experiments conducted around the time of calving. In this study, we tested the hypothesis that metabolic alkalosis induced by diet can induce resistance of target tissues to PTH stimulation in a late-gestation cow model. Using this model, we were able to isolate the effect of high-DCAD diet separately from other risk factors, such as excessive dietary phosphorus and inadequate diet $\mathrm{Mg}$.

\section{MATERIALS AND METHODS}

\section{Animals}

All procedures used on the cows in this study were approved by the US Department of Agriculture-Agricultural Research Service National Animal Disease Center's Institutional Animal Care and Use Committee. Jersey cows entering their third or greater lactation and in their last 2 mo of gestation, weighing from 490 to $545 \mathrm{~kg}$, participated in this study. They were fed either a low-DCAD $(\mathrm{n}=8)$ or a high-DCAD $(\mathrm{n}=8)$ diet for 2 wk (Table 1) to induce a state of metabolic acidosis or alkalosis before they were treated with PTH (Figure 1). The actual number of days before calving when the PTH treatment was begun averaged $28 \mathrm{~d}$, with a range from $6 \mathrm{~d}$ before calving to $41 \mathrm{~d}$ before calving. The trial was performed in 4 separate experimental periods using 4 cows with approximately the same expected calving dates (2 cows on each diet treatment) in each experimental period. The diets were formulated by mixing either reagent-grade $36 \%$ hydrochloric acid $(\mathrm{HCl})$ or potassium carbonate $\left(\mathrm{K}_{2} \mathrm{CO}_{3}\right)$ into a basal corn silage-grass hay ration to achieve DCAD of -181 and $+188 \mathrm{mEq} / \mathrm{kg}$ of DM for the low- and high-DCAD diets, respectively. Cows were housed individually in box stalls and limit fed $8.0 \mathrm{~kg}$ of diet/d (DM basis) to ensure complete intake of added anions or cations during the course of the trial. Orts were less than 0.75 $\mathrm{kg}$ of $\mathrm{DM} / \mathrm{d}$ in all cows and consisted primarily of corn cobs and some larger hay fibers.

The diets were also formulated to avoid other dietary factors identified as factors that increase the risk of hypocalcemia, allowing isolation of the effects of DCAD. The diets were $0.76 \% \mathrm{Ca}$, well below the levels the metaanalyses cited above have implicated as most likely to 
Table 1. Composition of low- and high-DCAD diets fed to lategestation cows for 2 wk before and during parathyroid hormone treatment

\begin{tabular}{|c|c|c|}
\hline Item & $\begin{array}{c}\text { Low } \\
\text { DCAD }\end{array}$ & $\begin{array}{l}\text { High } \\
\text { DCAD }\end{array}$ \\
\hline \multicolumn{3}{|l|}{ Ingredient, DM basis } \\
\hline Corn silage, $\mathrm{kg} / \mathrm{d}$ & 3.73 & 3.73 \\
\hline Prairie grass hay, $\mathrm{kg} / \mathrm{d}$ & 0.47 & 0.47 \\
\hline Distillers grains, kg/d & 0.99 & 0.99 \\
\hline Expeller soymeal $44 \% \mathrm{CP}, \mathrm{kg} / \mathrm{d}$ & 0.49 & 0.49 \\
\hline Beet pulp, $\mathrm{kg} / \mathrm{d}$ & 1.94 & 1.94 \\
\hline Salt-vitamin-mineral mix, ${ }^{1} \mathrm{~kg} / \mathrm{d}$ & 0.11 & 0.11 \\
\hline Dicalcium phosphate, g/d & 57 & 57 \\
\hline Calcium sulfate $2 \mathrm{H}_{2} \mathrm{O}, \mathrm{g} / \mathrm{d}$ & 65 & 65 \\
\hline Hydrochloric acid $(36 \% \mathrm{HCl}), \mathrm{g} / \mathrm{d}$ & 50 & 0 \\
\hline Potassium carbonate, $\mathrm{g} / \mathrm{d}$ & 0 & 110 \\
\hline \multicolumn{3}{|l|}{ Analysis } \\
\hline $\mathrm{CP}, \%$ & 13.9 & 13.8 \\
\hline RUP, \% & 6.5 & 6.5 \\
\hline Ether extract, \% & 3.6 & 3.6 \\
\hline NDF, $\%$ & 42.4 & 42.1 \\
\hline $\mathrm{ADF}, \%$ & 24.5 & 24.3 \\
\hline NFC, $\%$ & 36.6 & 35.9 \\
\hline $\mathrm{NE}_{\mathrm{L}}, \mathrm{Mcal} / \mathrm{kg}$ & 1.65 & 1.64 \\
\hline $\mathrm{Ca}, \%$ & 0.76 & 0.76 \\
\hline P, $\%$ & 0.41 & 0.40 \\
\hline $\mathrm{Na}, \%$ & 0.19 & 0.19 \\
\hline $\mathrm{K}, \%$ & 1.08 & 1.84 \\
\hline $\mathrm{Mg}, \%$ & 0.42 & 0.41 \\
\hline $\mathrm{Cl} \%$ & 1.01 & 0.40 \\
\hline S, $\%$ & 0.41 & 0.41 \\
\hline $\mathrm{DCAD},{ }^{2} \mathrm{mEq} / \mathrm{kg}$ & -181 & 188 \\
\hline
\end{tabular}

${ }^{1}$ Vitamin-mineral premix provided 3,300 IU of vitamin E, 25,000 IU of vitamin $\mathrm{D}_{3}, 80,000 \mathrm{IU}$ of vitamin $\mathrm{A}$ per day and trace minerals at levels above NRC (2001) requirements.

${ }^{2}$ Calculated using the formula $(\mathrm{Na}+\mathrm{K})-(\mathrm{Cl}+\mathrm{S})$.

induce milk fever. The diet supplied about $60 \mathrm{~g}$ of $\mathrm{Ca} / \mathrm{d}$, of which about $39 \mathrm{~g}$ is estimated to be absorbable using the NRC (2001) model. These dry cows are estimated to require just $16 \mathrm{~g}$ of absorbed $\mathrm{Ca} / \mathrm{d}$. The diets were $0.41 \% \mathrm{Mg}$, well in excess of NRC (2001) requirements. Energy, MP, trace minerals, and vitamins supplied by the diet were in excess of NRC (2001) requirements. Baseline blood and urine samples were collected from each cow the day before PTH treatment. Total urine collections were made from 0800 to $2000 \mathrm{~h}$ on the day before PTH treatment and again during the first $12 \mathrm{~h}$ of PTH treatment. On both days, the bladders of the cows were emptied by eliciting micturition just before 0800; that urine was not collected. Urine was collected by manual stimulation of the vulva to elicit micturition every $2 \mathrm{~h}$ and the urine was collected in a steel bucket. The volume of urine and its $\mathrm{pH}$ were recorded, and a $3-\mathrm{mL}$ aliquot was acidified using $100 \mu \mathrm{L}$ of glacial acetic acid and frozen at $-20^{\circ} \mathrm{C}$ until $\mathrm{Ca}, \mathrm{Mg}$, and creatinine concentrations were determined. Urine was also sampled at later time points for determination of ratios of $\mathrm{Ca}$ and $\mathrm{Mg}$ to creatinine but total volume was not measured on later samples.

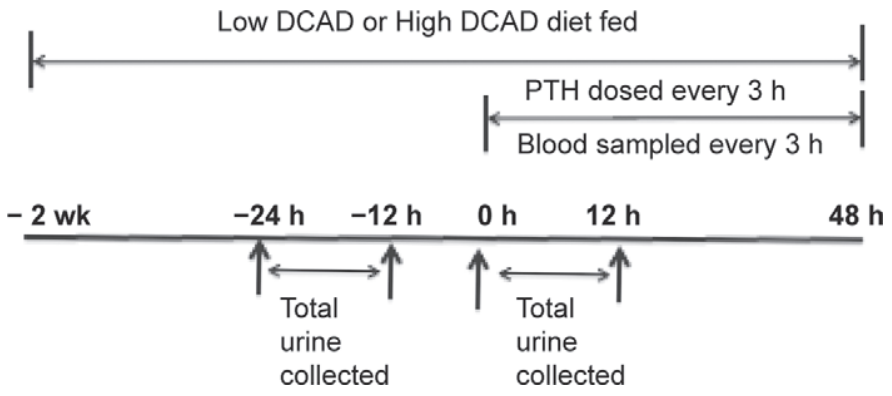

Figure 1. Experimental protocol timeline. A low- or high-DCAD diet was fed for 2 wk before the beginning of parathyroid hormone (PTH) administration. Doses of PTH were administered at time $0 \mathrm{~h}$ and repeated every $3 \mathrm{~h}$ for $48 \mathrm{~h}$. Blood samples were obtained just before each dose of PTH was administered. Total 12-h urine collections were made during the time from $24 \mathrm{~h}$ before $\mathrm{PTH}$ treatment started until $12 \mathrm{~h}$ before PTH started (0800 to $2000 \mathrm{~h}$ ) and again during the first $12 \mathrm{~h}$ of PTH treatment from time 0 to $12 \mathrm{~h}(0800$ to $2000 \mathrm{~h})$. Samples of urine elicited by micturition ( $20 \mathrm{~mL}$ of mid-stream urine) were also collected at intervals during the remaining $36 \mathrm{~h}$ of $\mathrm{PTH}$ treatment.

\section{PTH Treatment}

The synthetic, N-terminal 1-34 bovine PTH fragment used in this study was $69 \%$ pure and provided 4,142 IU of PTH/mg (Peninsula Labs Inc., San Carlos, CA; lot no. 9802082). The powdered PTH was weighed into a polyethylene tube that had been previously rinsed with $4 \%$ BSA (essentially fatty acid-free and globulin-free bovine albumin, Sigma Chemical Co., St. Louis, MO) to reduce nonspecific binding of PTH to the vessel walls. The PTH was then solubilized in slightly acidic $(0.001$ $N \mathrm{HCl}) \quad 0.85 \%$ saline containing $2 \%$ cysteine and $2 \%$ BSA, again to prevent PTH from nonspecifically binding to syringe walls. The PTH solvent had previously been sterilized by passage through a $45-\mu \mathrm{m}$ filter. Twomilliliter aliquots of this solution constituting a single dose of PTH for injection were kept frozen at $-20^{\circ} \mathrm{C}$ until use. Just before injection, a dose was removed from the freezer, allowed to thaw at room temperature, and drawn up into a 10-mL syringe containing $7 \mathrm{~mL}$ of $0.85 \%$ saline. Injections were made into the gluteal muscles using a 1.5-inch, 20 -gauge needle. The first dose of PTH given to each cow contained $5 \mathrm{mg}$ of PTH as a priming dose. Additional injections of $3.3 \mathrm{mg}$ of PTH were given every $3 \mathrm{~h}$ up to $\mathrm{h} 48$. Jugular venous heparinized blood samples were obtained from each cow just before PTH treatment and at 3-h intervals during the period of PTH administration. Plasma was obtained by centrifugation and stored at $-20^{\circ} \mathrm{C}$ until assayed. A second jugular venous blood sample was also obtained anaerobically in heparinized glass syringes before the first PTH injection and kept sealed at $4^{\circ} \mathrm{C}$ while being transported to the laboratory for determination of blood gas concentrations and pH (ABL 505 Blood 
Analyzer, Radiometer, Copenhagen, Denmark). The blood gas analyses were completed within $2 \mathrm{~h}$ of sample collection.

\section{Analyses}

Plasma and urine $\mathrm{Ca}$ and $\mathrm{Mg}$ concentrations were determined by atomic absorption spectrophotometry (Perkin-Elmer Corporation, 1965). Urine creatinine concentrations were determined by colorimetric assay (Chasson et al., 1961). Urine $\mathrm{pH}$ was determined within 20 min of collection (Corning pH meter, Corning, NY). Plasma $1,25(\mathrm{OH})_{2} \mathrm{D}$ concentrations were determined by radioimmunoassay using iodinated $1,25(\mathrm{OH})_{2} \mathrm{D}_{3}$ as tracer (Hollis et al., 1996) with a commercial kit (Diasorin, Stillwater, MN). Assays were performed so that samples from a cow on each diet treatment were paired in the same assay. This assay has a limit of detection of $2.4 \mathrm{pg} / \mathrm{mL}$, within-assay coefficient of variation of $10.4 \%$, and between-assay coefficient of variation of $11.4 \%$.

Carboxyterminal telopeptide of type I collagen (CTX) is an end-product of cathepsin-K-mediated type I collagen turnover and is used as an index of osteoclast bone resorption activity. Serum levels of epitopes of the CTX released into the blood during osteoclast bone collagen digestion were determined at $0,15,33$, and $48 \mathrm{~h}$ of PTH treatment. Serum CTX concentrations were measured using a one-step ELISA (Osteometer, Biotech, Copenhagen, Denmark). This test is based on 2 specific monoclonal antibodies directed against AA sequences within the CTX. The CTX assay has been used in human samples to assess bone resorption rates and was previously validated for the bovine (Liesegang et al., 1998). For this study, CTX concentrations for all samples were determined in a single assay. As a check of the assay validity, serial dilutions of serum from a 3 -wkold calf (actively resorbing bone during growth and bone remodeling) were included in the assay and the assay performed in a linear fashion to known standards included with the kit until CTX concentrations were $<0.1 \mathrm{ng} / \mathrm{mL}$, confirming the validation by Liesegang et al. (1998).

\section{Statistical Analysis}

Data on blood Ca, Mg, $1,25(\mathrm{OH})_{2} \mathrm{D}$, and CTX concentrations and on urine Ca:creatinine and Mg:creatinine ratios were subjected to repeated-measures ANOVA (SAS 8.2, SAS Institute Inc., Cary, NC). Cow nested within dietary treatment was the subject, and hour of PTH treatment was the repeated measure. The autoregressive covariance structure was used because it yielded the Akaike information criterion that was closest to zero (Littell et al.,1998). The main effects included in the initial model were diet (low DCAD, high DCAD), experimental period (1-4), and hour of PTH treatment. We were concerned that the use of 4 cows in each experimental period might have an effect in that cows that went through the protocol at one time might react differently from cows that were treated with PTH at a different time of replication of the dietary treatments. The full model suggested that experimental period had no significant effect on the outcome of the study; thus, experimental period was dropped from the final model. The final repeated-measures ANOVA model included diet, hour of PTH treatment, and the interaction between diet and hour of PTH treatment as main effects. When ANOVA indicated a significant effect at $P<$ 0.05 , post hoc pairwise testing of differences between least squares means was performed, using the Tukey adjustment for the number of tests performed.

Data from the first $15 \mathrm{~h}$ of PTH treatment were examined for the rate of change in $\mathrm{Ca}, 1,25(\mathrm{OH})_{2} \mathrm{D}$, and CTX by determining the trendline between data points at time 0 and $15 \mathrm{~h}$ of PTH treatment. The slope of this line was determined for each individual cow and the means across the 2 treatments were compared by Student's $t$-test. The 15 -h time point was chosen because after that time PTH administration was inducing hypercalcemia in the low-DCAD cows, which likely initiated Ca homeostatic responses antagonistic to the action of PTH, such as calcitonin secretion, to return plasma Ca to normal levels. Calcitonin would quickly reduce bone osteoclast activity (Zaidi et al., 2002). Hypercalcemia (directly) and calcitonin can also downregulate the renal production of $1,25(\mathrm{OH})_{2} \mathrm{D}$ (Hove et al., 1984; Omdahl et al., 2002). Data on total urine Ca excretion, blood gas concentration, and blood and urine $\mathrm{pH}$ as affected by diet before the first PTH injection were compared across the 2 treatments by Student's $t$-test.

\section{RESULTS AND DISCUSSION}

\section{Diet Effects on Acid-Base Status}

After 2 wk on the experimental diets and just before treatment with $\mathrm{PTH}$ was initiated, the urine $\mathrm{pH}$ and blood $\mathrm{pH}$ of cows on the low-DCAD diet were significantly lower $(P<0.01)$ than in cows fed the high-DCAD diet (Figure 2). Blood bicarbonate concentrations were also significantly lower $(P<0.01)$ in the low-DCAD cows (data not shown). The relatively high chloride, low $\mathrm{K}$ content of the low-DCAD diet induced a metabolic acidosis, with respiratory compensation driving blood bicarbonate slightly below normal. The relatively low chloride, high $\mathrm{K}$ content of the high-DCAD diet 
induced a compensated metabolic alkalosis in the cows. Urinary excretion of Ca determined in the $12 \mathrm{~h}$ from 0800 to $2000 \mathrm{~h}$ the day before PTH treatment was almost 10-fold greater in cows fed the low-DCAD diet $(3.59 \pm 0.16 \mathrm{~g})$ than in the high-DCAD cows $(0.39 \pm$ 0.19 g; $P<0.001)$. Plasma Ca concentration before the initiation of PTH treatment was slightly higher in highDCAD cows than in low-DCAD cows $(P<0.07)$, which may have been a result of the extra Ca lost to urine in the low-DCAD cows (Figure 3). Higher blood Ca in the high-DCAD cows more likely occurred because alkalosis reduces the fraction of total $\mathrm{Ca}$ that is in the ionized state and $\mathrm{Ca}$ homeostasis is driven by plasma ionized $\mathrm{Ca}$ concentration. It is likely that ionized $\mathrm{Ca}$ concentration in both groups of cows was similar and that this could be achieved with lower total $\mathrm{Ca}$ in lowDCAD cows (Oberleithner et al., 1982).

Plasma Mg concentrations were above $2.2 \mathrm{mg} / \mathrm{dL}$ in both groups, well above the renal threshold level of 1.9 $\mathrm{mg} / \mathrm{dL}$ (Goff, 1999), indicating that Mg status was adequate in both groups (Figure 4). Urinary Mg loss during the 12 -h period before PTH treatment was similar across both diets, again suggesting that Mg status was similar in both groups and not a confounding factor in this study. This is important to point out because a low plasma $\mathrm{Mg}$ concentration is known to increase the risk of hypocalcemia in cows. Hypomagnesemia can reduce endogenous PTH secretion (Littledike and Goff, 1987; Rude and Gruber, 2004) and strong evidence exists that it also reduces bone and kidney responsiveness to

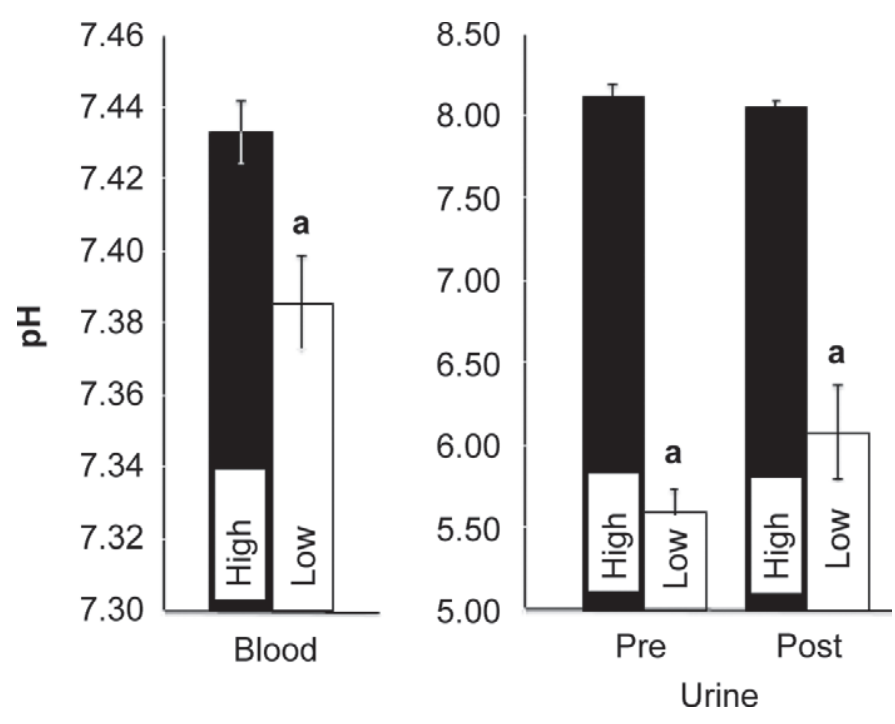

Figure 2. Blood and urine $\mathrm{pH}$ of cows fed the low- or high-DCAD diets. Blood $\mathrm{pH}$ was determined on blood collected immediately before the first dose of parathyroid hormone (PTH) was administered. Urine samples were obtained during the periods before (Pre) and after (Post) PTH administration. Results are means \pm SEM; ${ }^{a}$ significantly different from high-DCAD cow $\mathrm{pH}(P<0.01)$.

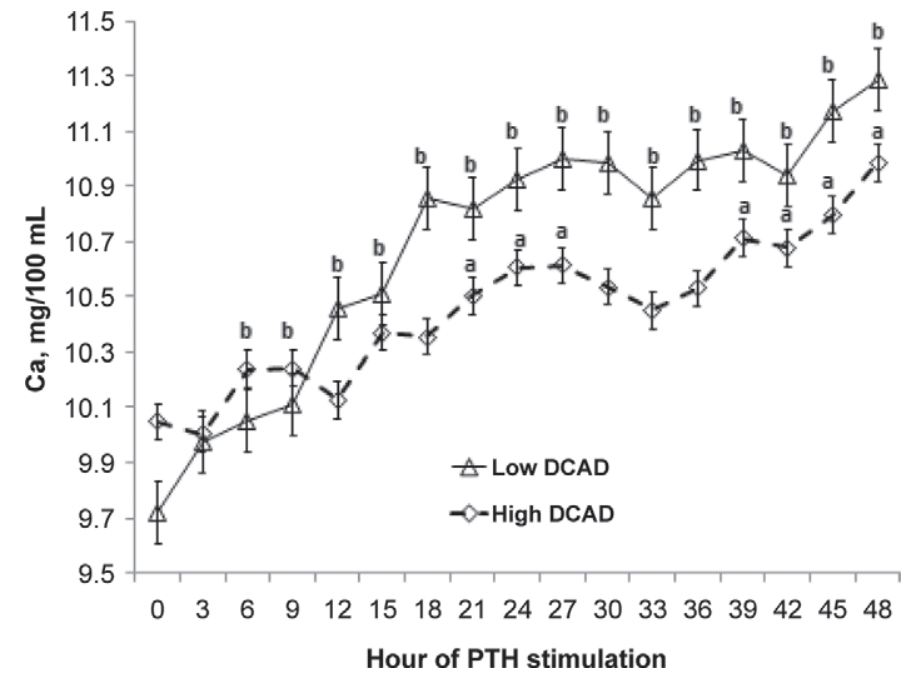

Figure 3. Plasma Ca concentration in cows fed low- or high-DCAD diets before and during the period of administration of parathyroid hormone (PTH). The PTH was administered every $3 \mathrm{~h}$ beginning immediately after the time 0 blood sample was obtained. Results are means \pm SEM; ${ }^{a}$ high-DCAD cow plasma Ca significantly different from that at time $0(P<0.05)$. ${ }^{b}$ low-DCAD cow plasma Ca significantly different from that at time $0(P<0.05)$.

PTH (Contreras et al., 1982; van de Braak et al., 1987; Rude and Gruber, 2004).

\section{Response to PTH Administration}

Repeated-measures ANOVA demonstrated significant time, diet, and time $\times$ diet interactions on both plasma $\mathrm{Ca}$ and $1,25(\mathrm{OH})_{2} \mathrm{D}$ concentrations. Cows fed the low-DCAD diet exhibited a significant increase $(P$ $<0.05$ ) in plasma Ca concentration from baseline (time 0) concentrations by $6 \mathrm{~h}$ of PTH treatment, and plasma Ca continued to increase throughout the experiment. In high-DCAD cows, plasma Ca concentration was not significantly increased from baseline concentration until $21 \mathrm{~h}$ of PTH treatment and continued to increase only slowly thereafter (Figure 3). The mean slope of the change in blood $\mathrm{Ca}$ concentrations during the first $15 \mathrm{~h}$ of PTH treatment, before development of marked hypercalcemia, was $0.052 \pm 0.011 \mathrm{mg} / \mathrm{dL}$ per hour in the low-DCAD diet cows. This was 2.7 times $(P<0.05)$ the rate of plasma $\mathrm{Ca}$ change in the high-DCAD diet cows, where Ca increased by $0.019 \pm 0.008 \mathrm{mg} / \mathrm{dL}$ per hour during the first $15 \mathrm{~h}$ of PTH treatment.

Plasma $1,25(\mathrm{OH})_{2} \mathrm{D}$ concentration was significantly $(P<0.05)$ increased above baseline (time 0$)$ in lowDCAD cows at $6 \mathrm{~h}$ of PTH treatment and continued to increase, peaking at $24 \mathrm{~h}$ of PTH treatment and remaining elevated thereafter. In high-DCAD cows, we observed a small but significant spike in plasma $1,25(\mathrm{OH})_{2} \mathrm{D}$ concentration at $6 \mathrm{~h}$ of $\mathrm{PTH}$ treatment, 


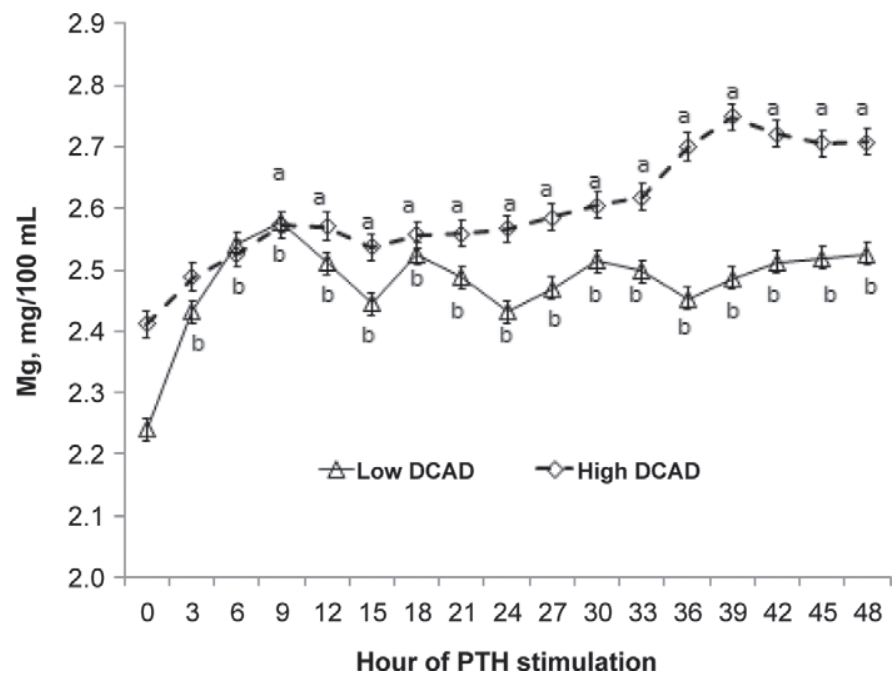

Figure 4. Plasma $\mathrm{Mg}$ concentration in cows fed low- or highDCAD diets before and during the period of administration of parathyroid hormone (PTH). The PTH was administered every $3 \mathrm{~h}$ beginning immediately after the time 0 blood sample was obtained. Results are means $\pm \mathrm{SEM}$; ${ }^{a}$ high-DCAD cow plasma $\mathrm{Mg}$ significantly different from that at time $0(P<0.05)$. ${ }^{b}$ low-DCAD cow plasma $\mathrm{Mg}$ significantly different from that at time $0(P<0.05)$.

but values at 9 and $12 \mathrm{~h}$ of PTH treatment were not significantly elevated from baseline. In the high-DCAD cows, the plasma $1,25(\mathrm{OH})_{2} \mathrm{D}$ concentration increased significantly above baseline (time 0 ) at 15, 24, 30, and $33 \mathrm{~h}$ of PTH treatment but were statistically similar to baseline levels at 18,21 , and $27 \mathrm{~h}$ of PTH treatment (Figure 5). Plasma $1,25(\mathrm{OH})_{2} \mathrm{D}$ concentrations increased 3.15-fold faster during the first $15 \mathrm{~h}$ of PTH treatment in low-DCAD diet cows $(4.29 \pm 0.64 \mathrm{pg} / \mathrm{mL}$ per hour) than in the high-DCAD diet cows $(1.36 \pm$ $0.73 \mathrm{pg} / \mathrm{mL}$ per hour; $P<0.02)$. In periparturient cows, feeding high-DCAD diets is associated with decreased renal production of $1,25(\mathrm{OH})_{2} \mathrm{D}$ as hypocalcemia developed (Gaynor et al., 1989; Goff et al., 1991; Phillippo et al., 1994). Failure to produce adequate $1,25(\mathrm{OH})_{2} \mathrm{D}$ would be expected to reduce the ability to utilize diet Ca efficiently. In one of the most comprehensive studies on DCAD effects in ruminants conducted, Fredeen et al. (1988) were able to feed high- and low-DCAD diets to goats and were able to conduct $\mathrm{Ca}$ absorption studies utilizing $\mathrm{Ca}^{45}$. They determined that low-DCAD diets increased intestinal absorption of $\mathrm{Ca}$ (Fredeen et al., 1988).

Only time had a significant effect on osteoclastic bone resorption, as indicated by serum CTX concentration. We observed a significant increase in serum CTX concentration by the 15-h time point in both groups. Only a small additional increase in serum CTX was observed as PTH treatment continued beyond that time in either dietary group (Figure 6). Serum CTX tended to be higher in cows fed the low-DCAD diet but the difference was not statistically significant. The slope of the line drawn based on plasma CTX concentration at 0 and $15 \mathrm{~h}$ of treatment indicated that plasma CTX increased in both dietary treatment groups at essentially the same rate $(0.020 \pm 0.006$ vs. $0.015 \pm 0.006 \mathrm{ng} / \mathrm{mL}$ per hour in the low- and high-DCAD cows, respectively). If a difference in bone resorption activity occurred across these 2 diets, our model lacked the statistical power to discern the difference. However, Fredeen et al. (1988) performed $\mathrm{Ca}^{45}$ tracer studies in goats and found that feeding a low-DCAD diet enhanced release of $\mathrm{Ca}$ from bone when the goats were subjected to a calcium challenge. In a periparturient cow model, Leclerc and Block (1989) demonstrated higher serum hydroxyproline concentration in cows fed a low-DCAD diet, and this was associated with improved Ca status at calving.

During the first $12 \mathrm{~h}$ of PTH treatment, urinary Ca loss was reduced from $3.59 \pm 0.16$ to $3.01 \pm 0.24 \mathrm{~g} / 12 \mathrm{~h}$ in the low-DCAD cows. The low-DCAD cows excreted $0.58 \mathrm{~g}$ less Ca during PTH treatment than they did the day before PTH treatment. This represents a $16 \%$ reduction in urine $\mathrm{Ca}$ with $\mathrm{PTH}$ stimulation. In the high-DCAD cows, urine Ca excretion was reduced from $0.39 \pm 0.19$ to $0.27 \pm 0.13 \mathrm{~g} / 12 \mathrm{~h}$ during the first $12 \mathrm{~h}$ of PTH treatment. The high-DCAD cows excreted 0.12 $\mathrm{g}$ less Ca than they did the day before PTH treatment. This represents a $30 \%$ reduction in urine Ca with PTH stimulation. As baseline (time 0) urinary Ca excretion was so different across diet treatments, it is not possible

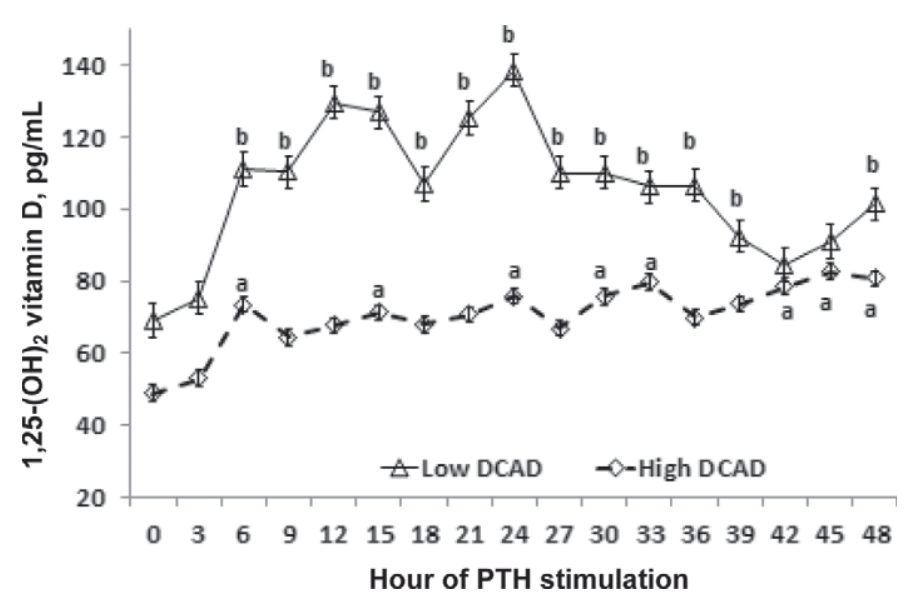

Figure 5. Plasma 1,25-dihydroxyvitamin D $\left[1,25\left(\mathrm{OH}_{2}\right)\right.$ vitamin $\left.\mathrm{D}\right]$ concentration in cows fed low- or high-DCAD diets before and during the period of administration of parathyroid hormone (PTH). The PTH was administered every $3 \mathrm{~h}$ beginning immediately after the time 0 blood sample was obtained. Results are means \pm SEM; ${ }^{a}$ high-DCAD cow plasma $1,25\left(\mathrm{OH}_{2}\right)$ vitamin $\mathrm{D}$ significantly different from that at time $0(P<0.05)$. blow-DCAD cow plasma $1,25\left(\mathrm{OH}_{2}\right)$ vitamin D significantly different from that at time $0(P<0.05)$. 


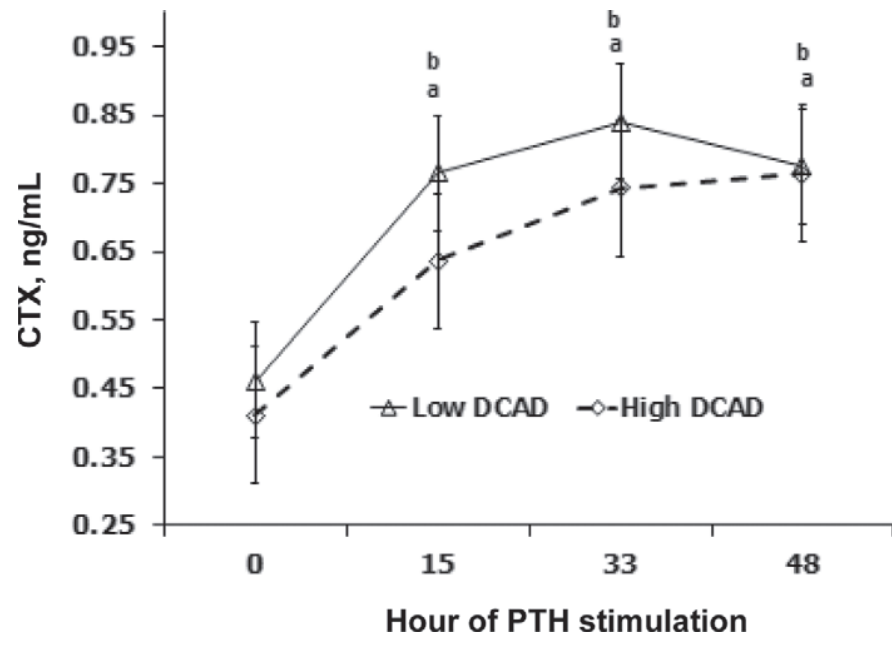

Figure 6. Plasma carboxyterminal telopeptide of type I collagen (CTX) concentration in cows fed low- or high-DCAD diets before and during the period of administration of parathyroid hormone (PTH). The PTH was administered every $3 \mathrm{~h}$ beginning immediately after the time 0 blood sample was obtained. Results are means \pm SEM; ${ }^{\text {ahigh- }}$ DCAD cow plasma CTX significantly different from that at time $0(P$

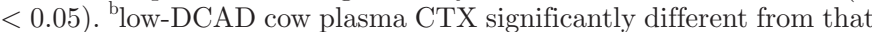
at time $0(P<0.05)$.

to interpret the effect of diet on PTH sensitivity of renal calcium reabsorption.

Because cows fed low-DCAD diets do excrete more $\mathrm{Ca}$ in their urine, it has been suggested that renal reabsorption of this potential pool of $\mathrm{Ca}(5-7 \mathrm{~g}$ of $\mathrm{Ca} / \mathrm{d})$ could provide the Ca needed to prevent development of hypocalcemia and milk fever. Schonewille et al. (1999) fed low-DCAD diets to cows and noted that they excreted about $6 \mathrm{~g}$ of $\mathrm{Ca} / \mathrm{d}$ via the urine. When they then challenged the cow's Ca homeostasis mechanisms by intravenous infusion with sodium EDTA to reduce blood ionized $\mathrm{Ca}$ and induce PTH secretion, they found that urinary $\mathrm{Ca}$ excretion declined to almost zero. Their data suggested that the extra $6 \mathrm{~g}$ of Ca normally excreted into the diet on a low-DCAD diet was returned to the blood and could help the cow maintain Ca homeostasis.

Our data do not replicate the near-complete reabsorption of Ca from urine found in the Schonewille et al. (1999) study. In the face of continued production of acidic urine, our low-DCAD cows were only able to reabsorb a small portion of the $\mathrm{Ca}$ in the glomerular filtrate when treated with PTH. Urine Ca:creatinine ratios did not decrease significantly in either diet group during the administration of PTH in our study (Figure 7). Our model did not impose a Ca challenge upon the cows as did the model of Schonewille et al. (1999), and it may be a mistake to dismiss the importance of urine Ca reabsorption as an aspect of low-DCAD diet mechanism of action in preventing milk fever.

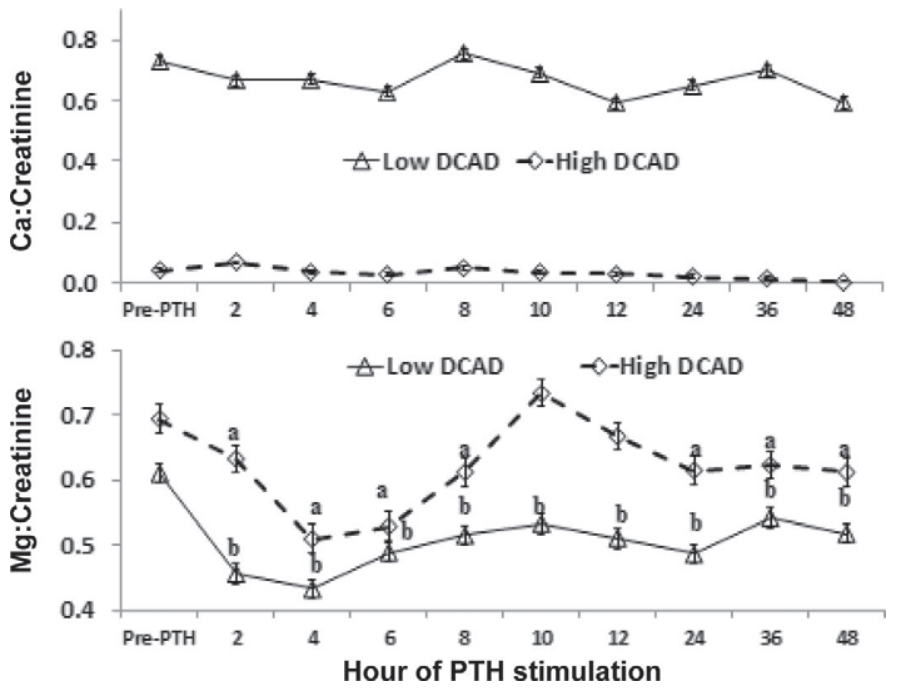

Figure 7. Urine Ca:creatinine ratio and $\mathrm{Mg}$ :creatinine ratio in cows fed low- or high-DCAD diets before parathyroid hormone (PTH) was administered and at intervals during the period of administration. The PTH was administered every $3 \mathrm{~h}$ beginning immediately after the time 0 blood sample was obtained. Results are means \pm SEM; ahigh-DCAD cow urine Ca:creatinine or Mg:creatinine ratio significantly different from that at time $0(P<0.05)$. ${ }^{b}$ low-DCAD cow urine Ca:creatinine or Mg:creatinine ratio significantly different from that at time $0(P<0.05)$.

Parathyroid hormone should increase the renal threshold for Mg excretion by the kidney. This should result in an increase in plasma $\mathrm{Mg}$ and a reduction in urine $\mathrm{Mg}$ :creatinine ratio as more of the $\mathrm{Mg}$ is reabsorbed from the glomerular filtrate (Goff, 1999). During the first $9 \mathrm{~h}$ of PTH treatment, plasma $\mathrm{Mg}$ increased in both groups of cows (Figure 2). The rate of increase in plasma $\mathrm{Mg}$ was greater in cows fed the low-DCAD diet during the first $9 \mathrm{~h}$, but this may reflect the fact that their baseline plasma $\mathrm{Mg}$ was lower than that in the high-DCAD cows. Urine Mg:creatinine ratios decreased in both low- and high-DCAD cows upon PTH treatment at a similar rate despite differences in baseline (time 0) Mg:creatinine ratios (Figure 7).

Taken together, our data demonstrate that the highDCAD diet induced a compensated metabolic alkalosis, which reduced the ability of the cows to respond to PTH. The diet induced a state of pseudohypoparathyroidism. Neither dietary Ca nor $\mathrm{Mg}$ differed across treatments, so neither can be considered a factor influencing tissue response to PTH in this study. Mayer et al. (1969) had already demonstrated that the parathyroid glands recognize the onset of hypocalcemia in milk fever cows and the parathyroid glands respond by greatly increasing PTH secretion. Martig and Mayer (1973) originally suggested that pseudohypoparathyroidism was the cause of milk fever because the response of late-gestation 
cows to injections of parathyroid extracts was greatly decreased compared with that of mid-lactation cows. In human medicine, people diagnosed with pseudohypoparathyroidism have been identified as being resistant to the effects of PTH. They often have hypocalcemia and very high circulating serum levels of PTH. The inability of these people to respond to PTH is often due to a genetic defect in the G-stimulatory protein coupled to the PTH receptor, which when properly activated by PTH, should result in intracellular accumulation of the second messenger, cyclic AMP. Our data support the observations of Martig and Mayer (1973) that transient pseudohypoparathyroidism is a major factor contributing to hypocalcemia and milk fever. An argument can be made that testing tissue responsiveness several weeks before parturition does not reflect how the tissues will respond at the time of calving. Unfortunately, testing tissue responsiveness in periparturient cows is complicated by many factors. Goff et al. (1989) and Phillippo et al. (1994) saw diminished production of $1,25(\mathrm{OH})_{2} \mathrm{D}$ in the face of elevated PTH in periparturient cows fed alkalogenic high-DCAD diets. This suggests that the model we used is translatable to the periparturient cow and demonstrates that diet DCAD can influence response of tissues to PTH, and that blood $\mathrm{pH}$ is an integral part of the diet DCAD effect. The influence of acid-base status on calcium metabolism is not restricted to the ruminant. Beck and Webster (1976) observed that acute metabolic acidosis directly increases Ca mobilization from rat bone and augments the effect of PTH to mobilize calcium from bone. In their studies, acidosis directly inhibited renal tubular reabsorption of calcium, but augmented the effect of PTH to increase renal tubular reabsorption of calcium. Martin et al. (1980) found that the uptake of PTH by isolated perfused dog bone was enhanced under conditions of metabolic acidosis, resulting in greater release of cyclic AMP, the second messenger elicited when PTH binds to its receptor.

Acid-base status has been shown to affect responsiveness of tissues to other hormones as well. Under conditions of metabolic acidosis, hepatocytes fail to respond to growth hormone by producing insulin-like growth factor-I (Brüngger et al., 1997). Acidosis can also induce insulin resistance in tissues, complicating treatment of diabetes in humans, and may play a role in ketosis of cows (Bigner et al., 1996; Mitch, 2006). Metabolic acidosis alters the tertiary structure of the insulin receptor, reducing its affinity for insulin. It does not alter receptor number (Igarashi et al., 1993). In the case of the dairy cow, our data support that the condition of metabolic alkalosis induced by a high-DCAD diet results in a poor response of Ca regulating tissues to PTH resulting in acute hypocalcemia, which is some- times so severe as to result in milk fever. The typical dairy cow diet before calving is relatively high in $\mathrm{K}$. This induces a metabolic alkalosis, causing a state of pseudohypoparathyroidism, and preventing rapid successful adaptation of the cow to the Ca demands of lactation. We speculate that the tertiary structure of the PTH receptor-G-protein complex is altered during metabolic alkalosis, reducing its affinity for PTH and resulting in pseudohypoparathyroidism. The loss of tissue sensitivity to PTH is not a total loss of ability to respond, as it is in humans with mutations in the PTH receptor-G-protein complex. In cattle, it appears to be a reduction in response, because very high levels of PTH over an extended period can eventually overcome the tissue resistance to PTH. For example, feeding very low $\mathrm{Ca}$ diets (less $\mathrm{Ca}$ absorbed than the cow requires) to stimulate endogenous PTH secretion in the weeks before calving and exogenous administration of pharmacologic doses of PTH for several days just before calving have both been successfully used to prevent milk fever, even when diet DCAD was high (Goings et al., 1974; Green et al., 1981; Goff et al., 1986). LowDCAD diets induce a compensated metabolic acidosis that restores tissue sensitivity to PTH. This allows Ca homeostasis to proceed normally and returns blood Ca to normal quickly, preventing development of subclinical hypocalcemia or milk fever.

\section{REFERENCES}

Beck, N., and S. K. Webster. 1976. Effects of acute metabolic acidosis on parathyroid hormone action and calcium mobilization. Am. J. Physiol. 230:127-131.

Bigner, D. R., J. P. Goff, M. A. Faust, J. L. Burton, H. D. Tyler, and R. L. Horst. 1996. Acidosis effects on insulin response during glucose tolerance tests in Jersey cows. J. Dairy Sci. 79:2182-2188.

Block, E. 1984. Manipulating dietary anions and cations for prepartum dairy cows to reduce incidence of milk fever. J. Dairy Sci. 67:2939-2948.

Brüngger, M., H. N. Hulter, and R. Krapf. 1997. Effect of chronic metabolic acidosis on the growth hormone/IGF-1 endocrine axis: New cause of growth hormone insensitivity in humans. Kidney Int. 51:216-221.

Capen, C. C., and D. M. Young. 1967. The ultrastructure of the parathyroid glands and thyroid parafollicular cells of cows with parturient paresis and hypocalcemia. Lab. Invest. 17:717-737.

Charbonneau, E., D. Pellerin, and G. R. Oetzel. 2006. Impact of lowering dietary cation-anion difference in nonlactating dairy cows: A meta-analysis. J. Dairy Sci. 89:537-548.

Chasson, A. L., H. J. Grady, and M. A. Stanley. 1961. Determination of creatinine by means of automatic chemical analysis. Am. J. Clin. Pathol. 35:83-88.

Contreras, P. A., R. Manston, and B. F. Sansom. 1982. Calcium homeostasis in hypomagnesaemic cattle. Res. Vet. Sci. 33:10-16.

Dishington, I. W. 1975. Prevention of milk fever by dietary salt supplements. Acta Vet. Scand. 16:503-512.

Ender, F., I. W. Dishington, and A. Helgebostad. 1971. Calcium balance studies in dairy cows under experimental induction and prevention of hypocalcaemic paresis puerperalis. The solution of the aetiology and the prevention of milk fever by dietary means. Z . Tierphysiol. Tierernahr. Futtermittelkd. 28:233-242. 
Fredeen, A. H., E. J. DePeters, and R. L. Baldwin. 1988. Effects of acid-base disturbances caused by differences in dietary fixed ion balance on kinetics of calcium metabolism in ruminants with high calcium demand. J. Anim. Sci. 66:174-184.

Gaynor, P. J., F. J. Mueller, J. K. Miller, N. Ramsey, J. P. Goff, and R. L. Horst. 1989. Parturient hypocalcemia in Jersey cows fed alfalfa haylage-based diets with different cation to anion ratios. J. Dairy Sci. $72: 2525-2531$.

Goff, J. P. 1999. Treatment of calcium, phosphorus, and magnesium balance disorders. Vet. Clin. North Am. Food Anim. Pract. 15:619-639.

Goff, J. P., and R. L. Horst. 1997. Effects of the addition of potassium or sodium, but not calcium, to prepartum rations on milk fever in dairy cows. J. Dairy Sci. 80:176-186.

Goff, J. P., R. L. Horst, F. J. Mueller, J. K. Miller, G. A. Kiess, and H. H. Dowlen. 1991. Addition of chloride to a prepartal diet high in cations increases 1,25-dihydroxyvitamin D response to hypocalcemia preventing milk fever. J. Dairy Sci. 74:3863-3871.

Goff, J. P., E. T. Littledike, and R. L. Horst. 1986. Effect of synthetic bovine parathyroid hormone in dairy cows: Prevention of hypocalcemic parturient paresis. J. Dairy Sci. 69:2278-2289.

Goff, J. P., T. A. Reinhardt, and R. L. Horst. 1989. Recurring hypocalcemia of bovine parturient paresis is associated with failure to produce 1,25-dihydroxyvitamin D. Endocrinology 125:49-53.

Goings, R. L., N. L. Jacobson, D. C. Beitz, E. T. Littledike, and K. D. Wiggers. 1974. Prevention of parturient paresis by a prepartum, calcium-deficient diet. J. Dairy Sci. 57:1184-1188.

Green, H. B., R. L. Horst, D. C. Beitz, and E. T. Littledike. 1981. Vitamin D metabolites in plasma of cows fed a prepartum lowcalcium diet for prevention of parturient hypocalcemia. J. Dairy Sci. 64:217-226.

Hollis, B. W., J. Q. Kamerud, A. Kurkowski, J. Beaulieu, and J. L. Napoli. 1996. Quantification of circulating 1,25-dihydroxyvitamin $\mathrm{D}$ by radioimmunoassay with ${ }^{125}$ I-labeled tracer. Clin. Chem. 42:586-592.

Hove, K., R. L. Horst, E. T. Littledike, and D. C. Beitz. 1984. Infusions of parathyroid hormone in ruminants: Hypercalcemia and reduced plasma 1,25-dihydroxyvitamin D concentrations. Endocrinology 114:897-903.

Igarashi, M., K. Yamatani, N. Fukase, M. Daimon, H. Ohnuma, A. Ogawa, M. Tominaga, and H. Sasaki. 1993. Effect of acidosis on insulin binding and glucose uptake in isolated rat adipocytes. Tohoku J. Exp. Med. 169:205-213.

Lean, I. J., P. J. DeGaris, D. M. McNeil, and E. Block. 2006. Hypocalcemia in dairy cows: Meta-analysis and dietary cation anion difference theory revisited. J. Dairy Sci. 89:669-684.

Leclerc, H., and E. Block. 1989. Effects of reducing dietary cationanion balance for prepartum dairy cows with specific reference to hypocalcemic parturient paresis. Can. J. Anim. Sci. 69:411-417.

Liesegang, A., M. L. Sassi, J. Risteli, R. Eicher, M. Wanner, and J. L. Riond. 1998. Comparison of bone resorption markers during hypocalcemia in dairy cows. J. Dairy Sci. 81:2614-2622.

Littell, R. C., P. R. Henry, and C. B. Ammerman. 1998. Statistical analysis of repeated measures data using SAS procedures. J. Anim. Sci. 76:1216-1231.
Littledike, E. T., and J. Goff. 1987. Interactions of calcium, phosphorus, magnesium and vitamin $\mathrm{D}$ that influence their status in domestic meat animals. J. Anim. Sci. 65:1727-1743.

Martig, J., and G. P. Mayer. 1973. Diminished hypercalcemic response to parathyroid extract in prepartum cows. J. Dairy Sci. 56:10421046 .

Martin, K. J., J. J. Freitag, E. Bellorin-Font, M. B. Conrades, S. Klahr, and E. Slatopolsky. 1980. The effect of acute acidosis on the uptake of parathyroid hormone and the production of adenosine $3^{\prime}, 5^{\prime}$-monophosphate by isolated perfused bone. Endocrinology 106:1607-1611.

Mayer, G. P., C. F. Ramberg Jr., D. S. Kronfeld, R. M. Buckle, L. M. Sherwood, G. D. Aurbach, and J. T. Potts Jr. 1969. Plasma parathyroid hormone concentration in hypocalcemic parturient cows. Am. J. Vet. Res. 30:1587-1597.

Mitch, W. E. 2006. Metabolic and clinical consequences of metabolic acidosis. J. Nephrol. 19(Suppl. 9):S70-S75.

NRC. 2001. Nutrient Requirements of Dairy Cattle. 7th ed. Natl. Acad. Press, Washington, DC.

Oberleithner, H., R. Greger, and F. Lang. 1982. The effect of respiratory and metabolic acid-base changes on ionized calcium concentration: In vivo and in vitro experiments in man and rat. Eur. J. Clin. Invest. 12:451-455.

Oetzel, G. R. 1991. Meta-analysis of nutritional risk factors for milk fever in dairy cattle. J. Dairy Sci. 74:3900-3912.

Omdahl, J. L., H. A. Morris, and B. K. May. 2002. Hydroxylase enzymes of the vitamin D pathway: Expression, function, and regulation. Annu. Rev. Nutr. 22:139-166.

Perkin-Elmer Corporation. 1965. Analytical methods for atomic absorption spectrophotometry. Perkin-Elmer Corp., Norwalk, CT.

Phillippo, M., G. W. Reid, and I. M. Nevison. 1994. Parturient hypocalcaemia in dairy cows: Effects of dietary acidity on plasma minerals and calciotrophic hormones. Res. Vet. Sci. 56:303-309.

Ramberg, C. F., Jr., E. K. Johnson, R. D. Fargo, and D. S. Kronfeld 1984. Calcium homeostasis in cows, with special reference to parturient hypocalcemia. Am. J. Physiol. 246:R698-R704.

Reinhardt, T. A., J. D. Lippolis, B. J. McCluskey, J. P. Goff, and R. L. Horst. 2011. Prevalence of subclinical hypocalcemia in dairy herds. Vet. J. 188:122-124.

Rude, R. K., and H. E. Gruber. 2004. Magnesium deficiency and osteoporosis: Animal and human observations. J. Nutr. Biochem. 15:710-716.

Schonewille, J. T., A. T. Van't Klooster, H. Wouterse, and A. C. Beynen. 1999. Hypocalcemia induced by intravenous administration of disodium ethylenediaminotetraacetate and its effects on excretion of calcium in urine of cows fed a high chloride diet. J. Dairy Sci. 82:1317-1324.

van de Braak, A. E., A. T. Van't Klooster, and A. Malestein. 1987. Influence of a deficient supply of magnesium during the dry period on the rate of calcium mobilization by dairy cows at parturition. Res. Vet. Sci. 42:101-108.

Zaidi, M., A. M. Inzerillo, B. S. Moonga, P. J. Bevis, and C. L. Huang, 2002. Forty years of calcitonin - Where are we now? A tribute to the work of Iain Macintyre, FRS. Bone 30:655-663. 